\title{
INFLUENCE OF ORGANIC MATTER AND IRON OXIDES ON THE COLOUR PROPERTIES OF A MICRITIC LIMESTONE FROM KEFALONIA
}

\author{
Christidis G.E. ${ }^{1}$, Sakellariou N. ${ }^{1}$, Repouskou E. ${ }^{1}$, and Markopoulos $\mathrm{Th}^{1}$. \\ ${ }^{1}$ Technical University of Crete, Department of Mineral Resources Engineering, 73100 Chania, \\ Greece, christid@mred.tuc.gr
}

\begin{abstract}
The influence of organic matter and iron oxides on the colour properties of an ultra-high purity micritic limestone from Kefalonia Island containing $99.7 \%$ calcite was studied. Colouring impurities, organic matter and iron-oxide, were added in the form of a xylitic lignite and a hematite-rich Fe-ore respectively. Both impurities decrease lightness $\left(L^{*}\right)$ and increase deviation from perfect white diffuser $\left(\Delta E^{*} a b\right)$ as well as redness and yellowness of calcite. Organic matter affects colour properties to a greater degree than iron oxides. The results obtained were used in a model, which predicts lightness and $\Delta \mathrm{E}^{\star}$ ab of white limestones and marbles from their $\mathrm{Fe}_{2} \mathrm{O}_{3}$ and organic carbon content. The theoretical values of $L^{*}$ and $\Delta E^{*}$ ab of a series of known limestones and calcitic marbles obtained from this model are comparable to experimental values determined using a colourimeter. Slight deviations between theoretical and experimental values are attributed to several factors, which include the different nature of iron oxides/oxyhydroxides (goethite or/and lepidocrocite and/or amorphous Fe-oxyhydroxides instead of hematite) and organic matter (kerogene instead of xylitic lignite) present in the carbonate rocks, the different particle size of calcite and impurities in the different carbonates, to the multiphase nature of the colouring impurities used in this study and to the possible existence of other Fe-rich phases such as Fe-carbonates in the limestones. The proposed model can facilitate quality control of limestone resources used as fillers and can be extended to dolomitic rocks.
\end{abstract}

\section{INTRODUCTION}

Fillers and extenders are inexpensive minerals, used almost entirely to lower cost and add solids to paints, paper, plastics, rubber and sealants (Carr et al. 1994; Naydowski et al. 2001). Included in this broad category are most clay minerals (kaolinite, talc, smectite, pyrophyllite, mica, asbestiform serpentine) along with non-clay minerals such as natural and precipitated calcium carbonate (GCC and PCC, respectively), wollastonite, feldspars, nepheline syenite, barite, diatomite, and silica among others. The performance of industrial fillers results both from the inherent characteristics of the mineral itself and from the nature of the impurities present (e.g. colouring impurities such as organic matter and various types of free oxides like iron titanium and manganese oxides) and the characteristics imparted by processing, e.g., beneficiation, grinding, classification, calcination, slurring, surface treatment. Important properties of fillers include hardness, particle size and shape, colour, refractive index and chemical properties.

Colour and particle size and shape properties of mineral fillers are of particular importance because they affect the properties of the end products (Adams 1993). Particle size and size distribution affect colour; the colour of white minerals produced by grinding becomes whiter as particle size decreases because the size of the diffuse reflectance unit decreases (Christidis et al. 2004). On the other hand, although the colouring impurities such as $\mathrm{Fe}$ and Ti-oxides and organic matter are known to adversely affect colour parameters (Christidis \& Scott 1997), the exact nature of their influence is unknown. The purpose of this contribution is to examine the influence of Fe-oxides and organic matter on important colour parameters of ground calcium carbonate fillers and to propose a model, which predicts significant colour properties of limestones from the concentration of iron ox- 
ides and organic matter. For this purpose we used an ultra high purity calcium carbonate as reference material.

\section{COLOUR MEASUREMENT-THE CIELAB SYSTEM}

The CIELAB colour system is the most suitable method of measuring object or surface colour properties. The main colour parameters determined by the CIELAB colour system are the parameters: $L^{*}$, which represents lightness on a scale of 0 (black) to 100 (pure white); $a^{*}$ which is the degree of redness if positive or greenness it negative; $b^{\star}$ which is the degree of yellowness if positive or blueness if negative (Billmeyer \& Saltzman 1981). The CIELAB values are calculated from the red green and blue filters of the colorimeters and are particularly suited to describing near white samples according to the following equations:

$$
\begin{aligned}
& L^{*}=116\left(Y / Y^{n}\right)^{1 / 3}-16 \\
& a^{*}=200\left[\left(\left(X / X^{n}\right)^{1 / 3}-\left(Y / Y^{n}\right)^{1 / 3}\right]\right. \\
& b^{*}=200\left[\left(\left(Z / Z^{n}\right)^{1 / 3}-\left(Y / Y^{n}\right)^{1 / 3}\right]\right.
\end{aligned}
$$

where $X, Y$ and $Z$ are the tristimulus values for the samples arising from the colourimetric system and $X^{n}, Y^{n}$ and $Z^{n}$ are those of a surface colour chosen as the nominal white stimulus. In this study we used perfect white diffuser, a theoretical white material, as nominal white.

Another useful parameter for describing white, which is given in the $\mathrm{BS} 3900(1986)$ is $\Delta \mathrm{E}^{\star} a b$. This index, describes the difference between the colour of a sample and pure white, using the values of $L^{*} a^{*}$ and $b^{\star}$.

\section{MATERIALS AND METHODS}

\subsection{Materials}

The source of calcium carbonate is an ultra-high purity micritic limestone from Kefalonia Island in Western Greece. The material, which is produced by IONIAN KALK SA, is derived from an Eocene-Oligocene unbedded chalk, with scattered intercalations of chert nodules. The maximum diameter of the nodules varies from a few $\mathrm{mm}$ to $\mathrm{ca} 1 \mathrm{~m}$. The nodules are removed selectively during extraction (IONIAN KALK SA pers. comm.). The limestone outcrop is extended and is usually fractured and strongly karstified in the upper horizons. It belongs to the Paxos Geotectonic Unit and has maximum thickness $100 \mathrm{~m}$ (Bergmann 1964). The limestone contains $99.70 \%$ calcite (Table 1), it has a high porosity (ca. 20\%) and average calcite crystal size $4.1 \mu \mathrm{m}$ in situ (Triantafyllou et al. 2003). Minor mineralogical constituents which constitute the insoluble residue are quartz and opaque minerals (colouring agents), ferric chromite and ilmenite and to a lesser degree sphalerite and chalcopyrite. Pyrite is absent. In the present study the material used was an industrial product with average grain size $3 \mu \mathrm{m}$ prepared by IONIAN KALK SA.

The source of organic carbon was an Upper Miocene-Lower Pleiocene xylitic lignite from the Florina basin (Kotis et al. 1992) with $50.83 \%$ organic C (Table 1). Finally, the source of iron oxides was a sedimentary Fe-ore from the Agios loannis mine in Lokris with $51.95 \% \mathrm{Fe}_{2} \mathrm{O}_{3}$ and a significant bauxitic component (Table 1). The Fe-ore consists of hematite, boehmite, and minor goethite, anatase, chlorite and quartz. The $\mathrm{Fe}_{2} \mathrm{O}_{3}$ content corresponds to about $50 \%$ hematite.

\subsection{Experimental Methods}

The mineralogical composition of the limestone and the Fe-ore was determined by $X$-ray diffraction (XRD) (SIEMENS D500 XRD, CuKa radiation, graphite monochromator, operating at $35 \mathrm{kV}$ and $35 \mathrm{~mA}$ ) and Scanning Electron Microscopy (SEM) (JEOL JSM 5400). The chemical composition of the limestone and the Fe-ore was determined with X-ray fluorescence (SIEMENS SR303 XRF) using pressed powder pellets. Finally, the organic carbon and the nitrogen and hydrogen contents of the lignite were determined with a LECO-600 CHN-analyzer. 
The Fe-ore and the xylitic lignite were dried at $105^{\circ} \mathrm{C}$ and ground in a ball mill so as to pass through a $75 \mu \mathrm{m}$ sieve. The colour properties of the end member ground materials and their mixtures were measured according to the CIELAB system using a Diffusion Systems abridged reflectance spectrophotometer with a $45^{\circ} / 90^{\circ}$ geometry and illuminant " $A$ " source. The spectrophotometer was calibrated against the perfect white diffuser by means of a ceramic plate standardized by British Ceramic Research Ltd. For determination of the colour parameters of the lignite a second dark grey glazed ceramic plate was used, which was calibrated against the standard ceramic plate described before.

Table 1. Major (wt.\%) chemical analyses of the limestone, the Fe-ore and the lignite. Data for the Kefalonia limestone are from Triantafyllou et al. (2003)

\begin{tabular}{lrrr}
\hline Sample & Limestone & Fe-ore & lignite \\
\hline $\mathrm{SiO}_{2}$ & 0.05 & 2.19 & N.A. \\
$\mathrm{TiO}_{2}$ & B.D.L & 3.31 & N.A. \\
$\mathrm{Al}_{2} \mathrm{O}_{3}$ & 0.12 & 33.91 & N.A. \\
$\mathrm{Fe}_{2} \mathrm{O}_{3 \mathrm{t}}$ & 0.02 & 51.95 & N.A. \\
$\mathrm{MnO}$ & B.D.L & 0.004 & N.A. \\
$\mathrm{MgO}$ & 0.35 & B.D.L. & N.A. \\
$\mathrm{CaO}$ & 55.20 & 0.13 & N.A. \\
$\mathrm{Na}_{2} \mathrm{O}$ & 0.02 & 0.06 & N.A. \\
$\mathrm{K}_{2} \mathrm{O}$ & 0.03 & 0.02 & N.A. \\
$\mathrm{P}_{2} \mathrm{O}_{5}$ & B.D.L & 0.05 & N.A. \\
LOI & 43.91 & 7.43 & N.A. \\
$\mathrm{C}$ & N.A. & N.A. & 50.83 \\
$\mathrm{H}$ & N.A. & N.A. & 5.17 \\
$\mathrm{~N}$ & N.A. & N.A. & 1.77 \\
Total & 99.70 & 99.03 & \\
\hline $\mathrm{N}$. A. not analy & B.D.L. below detection limit
\end{tabular}

N.A. not analyzed, B.D.L. below detection limit

\subsection{Preparation of binary and ternary mixtures}

Binary mixtures were prepared by limestone and ground lignite or Fe-ore (coloring impurities). The amount of impurity added varied between 0 and $2 \mathrm{wt} \%$, which corresponds to ca $1 \%$ of either organic carbon or hematite. Similarly, the ternary mixtures were prepared by addition of various amounts of lignite and Fe-ore. Maximum concentration of coloring impurities was 2 wt \%, corresponding to ca. $1 \%$ of organic carbon or hematite. The mixtures of the finely ground end members were mixed thoroughly in polypropylene vials under continuous agitation for 10 minutes in a mechanical shaker. In this manner we prepared 36 homogeneous powders with different compositions. Subsequently we measured colour properties, namely lightness $\left(L^{*}\right)$, deviation from perfect white diffuser $\left(\Delta E^{\star} a b\right)$, redness-greenness $\left(a^{*}\right)$ and yellowness-blueness $\left(b^{*}\right)$.

\section{RESULTS}

\subsection{Influence of organic carbon and iron ore impurities on the colour properties of calcite}

The evolution of $L^{*}$ with addition of lignite is shown in figure 1a. Lightness is affected adversely both by the presence of organic matter and by the presence of iron oxides. The influence of lignite on the lightness of calcite is described by a second order polynomial equation, while the dependence of lightness on the Fe-ore follows a linear trend. It is evident that the organic matter affects lightness of calcite to a greater degree than the Fe-ore. Also the influence of lignite on lightness is more significant for concentrations up to $1 \%$, corresponding to $0.5 \%$ organic carbon, becoming less significant at higher concentrations of organic carbon. 
Similar trends are observed for $\Delta \mathrm{E}^{*} \mathrm{ab}$, which increases with increasing amount of coloring agents, indicating that the quality of colour of calcite deteriorates (Fig. 1b). The dependence of $\Delta \mathrm{E}^{*} \mathrm{ab}$ on lignite is described by a dual linear trend, while the dependence of $\Delta \mathrm{E}^{*} \mathrm{ab}$ on Fe-oxides follows a single linear trend. Similar to lightness, the influence of lignite on $\Delta \mathrm{E}^{\star} a b$ is more significant for concentrations up to $1 \%$, decreasing thereafter. Since the slopes of the linear trends for Fe- oxides and high concentrations of lignite are identical, it follows that these impurities affect $\Delta E^{*} a b$ of the calcite studied, in a similar manner.

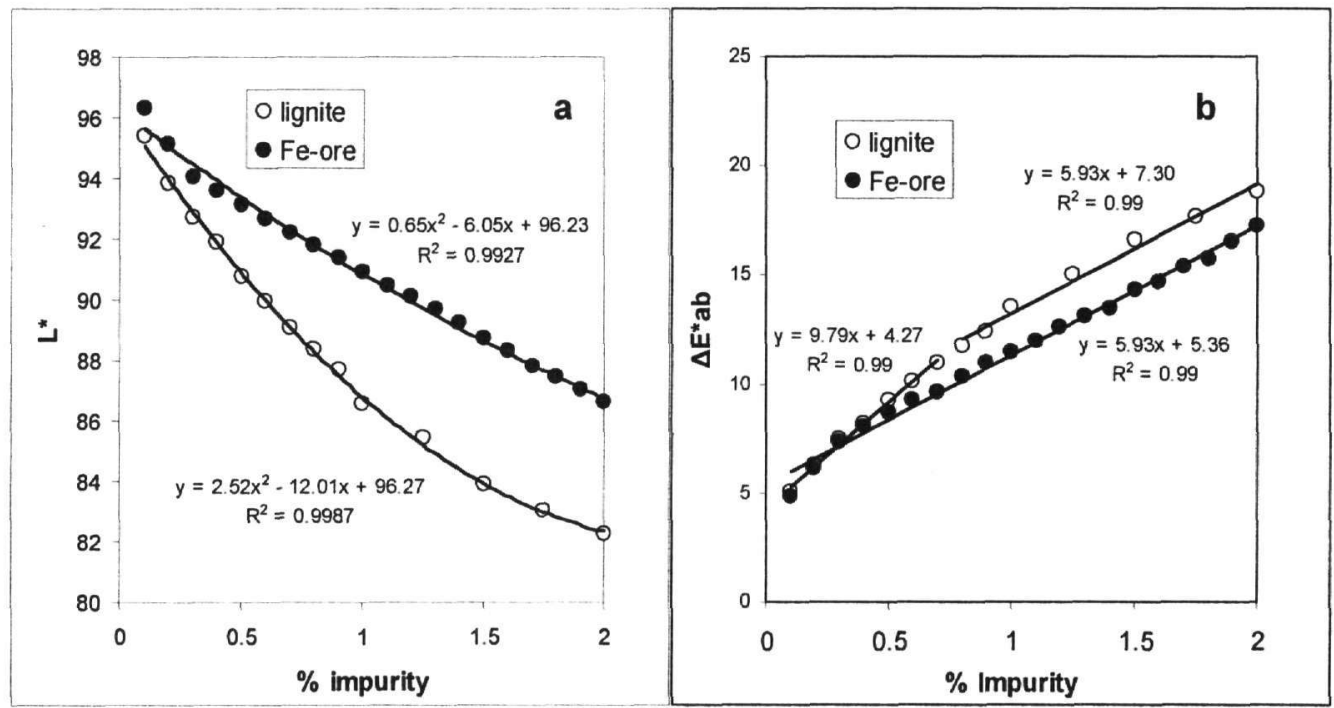

Figure 1. Dependence of lightness $\left(L^{\star}\right)(a)$ and $\Delta E^{\star} a b(b)$ of the Kefallonia limestone on the addition of lignite and Fe-ore impurities.

Redness-greenness (parameter $a^{*}$ ) and yellowness-blueness (parameter $b^{*}$ ) of calcite are also affected by organic matter and $\mathrm{Fe}$-oxides. The influence of $\mathrm{Fe}$-oxides and minor oxyhydroxides on parameters $a^{*}$ and $b^{*}$ is identical and can be described by linear trends with similar slopes (Fig. 2a). As expected, $a^{*}$ is positive (redness) throughout the entire range of concentrations used and increases with increasing amount of Fe-ore added. By contrast, the influence of organic matter on these parameters follows different trends. The dependence of $a^{*}$ on organic matter is described by a second order polynomial equation, while the dependence of $b^{*}$ on organic matter does not follow a certain trend (Fig. 2b). Similar to Fe-ore, parameter $a^{*}$ is always positive (redness) but b* follows a more complex trend at various lignite concentrations. Hence, it decreases gradually to negative values (blueness) with increasing lignite concentration up to $1 \%$, increasing thereafter and becomes positive. This complex behaviour is attributed to the multiphase nature of lignite, which contains a significant inorganic component. The latter contributes to the formation of bottom furnace ash and pulverized fuel ash during combustion in the coal power stations.

\subsection{Empirical model for prediction of colour properties of limestones.}

The empirical model for prediction of colour properties of limestones, namely $L^{\star}$ and $\Delta E^{\star} a b$, involves the construction of ternary diagrams, the apices of which are occupied by the end members, calcite, hematite and organic $\mathrm{C}$. The area of the diagrams contains contours, which correspond to different values of $L^{*}$ and $\Delta E^{*} a b$. The reason for the formulation of the model is to provide a means of prediction of these colour properties from important chemical constituents present in limestones with reasonable accuracy. Such a model is expected to facilitate quality control of limestones in the quarry level. An example from these ternary diagrams for lightness $\left(L^{*}\right)$ is shown in figure 3 . 


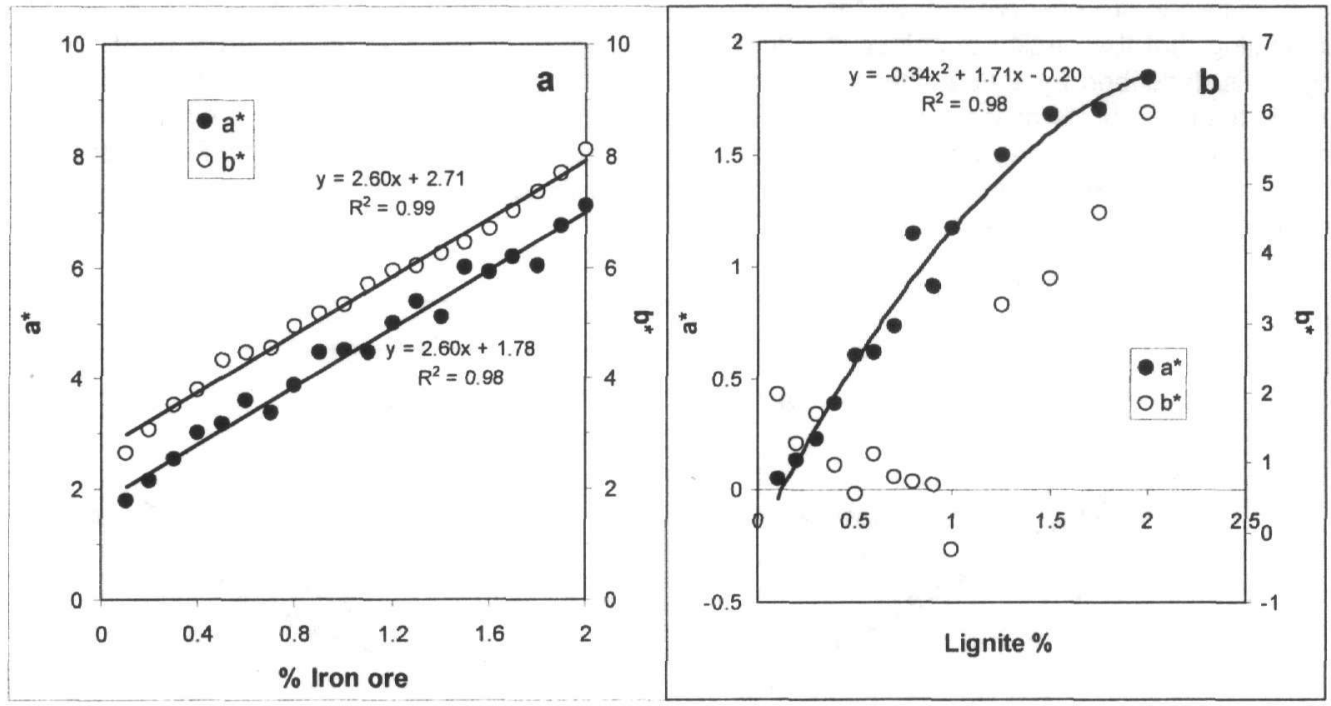

Figure 2. Dependence of redness $\left(a^{*}\right)$ and yellowness $\left(b^{*}\right)$ of the Kefallonia limestone on the addition of iron-ore (a) and lignite (b).

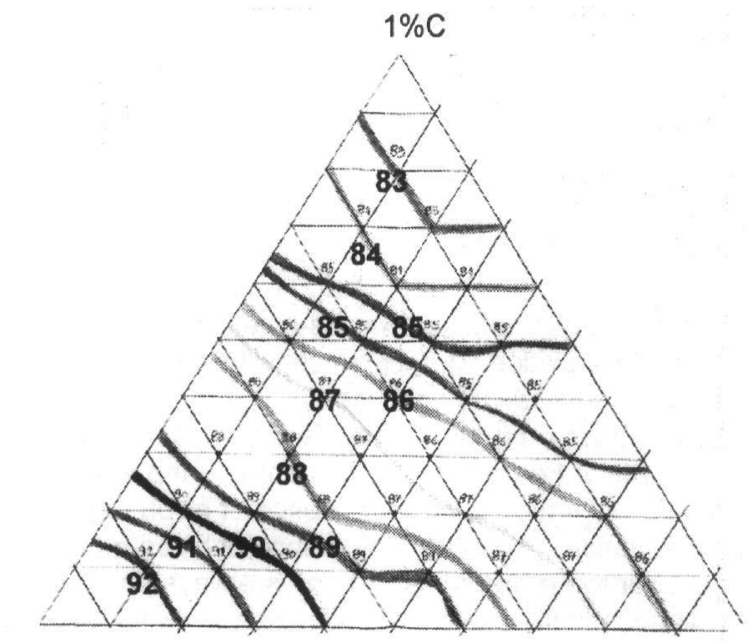

$\mathrm{CaCO}_{3}$

$1 \% \mathrm{Fe}_{2} \mathrm{O}_{3}$

Figure 3. Ternary plots depicting the evolution of lightness $\left(L^{*}\right)$ of the Kefallonia limestone after addition of lignite and iron-ore impurities.

The influence of added impurities on lightness is shown in Figure 3. It is obvious that addition of impurities decreases lightness. The contours are subparallel and a shift towards the $\mathrm{CaCO}_{3}$ apex is associated with increase of lightness. Similar results were obtained for $\Delta E^{*} a b$. In this case a shift towards the $\mathrm{CaCO}_{3}$ apex is associated with decrease of $\Delta \mathrm{E}^{*} \mathrm{ab}$. This is due to the adverse effect of impurities on the colour properties of limestone. Calcite is the mineral, which imparts white colour and any deviation from purity due to the presence of colouring constituents is associated with deterioration of colour parameters. 
The next step was to test the utility of these ternary diagrams on prediction of colour properties of carbonates. For this purpose we used a set of carbonate rocks from Crete, both limestones and marbles derived from different geotectonic units, namely Tripolis, Plattenkalk and Trypali geotectonic units. The colour properties of these materials have been described by Repouskou (2001), using the same colourimeter and the same light source as we used in this study. The carbonate rocks tested are rocks of high and very high purity with calcite content exceeding $98 \%$. The rocks have variable $\mathrm{Fe}_{2} \mathrm{O}_{3}$ contents, as determined by $\mathrm{XRF}$ and variable organic carbon content, as determined by weight loss after heating at $550^{\circ} \mathrm{C}$ (Repouskou 2001). Using the $\mathrm{Fe}_{2} \mathrm{O}_{3}$ and organic carbon contents lightness $\left(\mathrm{L}^{*}\right)$ and $\Delta \mathrm{E}^{\star} a b$ parameters were determined from ternary diagrams (e.g. Fig. 3) and were compared with the values determined by Repouskou (2001). The results are listed in Table 2.

It is evident that the values obtained using the ternary diagrams (theoretical values) are comparable to those determined experimentally using a colourimeter. There is a slight deviation between the two values mainly in the determination of $\Delta E^{*} a b$ (Table 2). By contrast, with one exception the theoretical values of $L^{*}$ are almost identical with the experimental values. This underlines the usefulness of the proposed model as discussed below. Inasmuch as the dataset used in this study to test the model contains both limestones and marbles, it follows that the model can be used for most types of carbonates rich in calcite. Moreover it is evident that the model is not affected either by the diagenetic or metamorphic history of the carbonate rocks or by the geotectonic unit in which these rocks belong.

Table 2. Comparison between the theoretical and experimental values of $L^{*}$ and $\Delta E^{*}$ ab obtained for various carbonate rocks of Crete. The theoretical values were obtained using the proposed model. The experimental values are from Repouskou (2001).

\begin{tabular}{ccccc}
\hline Sample & $\begin{array}{c}\text { Theoretical } \\
\text { value }\end{array}$ & $\begin{array}{c}\text { Experimental } \\
\text { value }\end{array}$ & $\begin{array}{c}\text { Standard } \\
\text { Deviation }\end{array}$ \\
\hline \multirow{4}{*}{$L^{*} \quad$ RODOPOS-4 } & 89.5 & 89.77 & 0.19 \\
& HARKIA-2 & 92.9 & 93.49 & 0.42 \\
& ASFENDOU-3 & 93.5 & 93.7 & 0.14 \\
& KRASI-7 & 92.9 & 92.88 & 0.01 \\
& RODOPOS-1 & 90 & 89.86 & 0.09 \\
\hline \multirow{4}{*}{$\Delta E^{*}$ ab } & RODOPOS-4 & 10.7 & 10.41 & 0.20 \\
& ASFENDOU-3 & 7.10 & 6.59 & 0.39 \\
& HARKIA-2 & 7.15 & 6.32 & 0.55 \\
& KRASI-7 & 7.4 & 7.70 & 0.21 \\
& RODOPOS-1 & 9.95 & 10.4 & 0.32 \\
\hline
\end{tabular}

\section{DISCUSSION}

This study showed that the proposed model could be used to predict important colour properties of carbonate rocks. It is a straightforward and fast method, which can facilitate routine industrial processes like quality control, because the $\mathrm{Fe}_{2} \mathrm{O}_{3}$ - and organic carbon contents are routinely determined in calcite fillers. Also it was shown that important colour properties of carbonates vary systematically with increasing contents of Fe-oxides/oxydydroxides and organic carbon impurities. These systematic trends will assist to understand colour variations often encountered in most deposits of carbonate rocks. However the standard deviation between the experimental and the theoretical values for the parameters studied is rather high in the case of $\Delta E^{*} a b$ (Table 2 ). This indicates that currently the proposed model cannot substitute for traditional colourimeters, due to the limited number of limestones used for calibration, unless it is calibrated sufficiently. Such a calibration may involve the use of a greater variety of limestones and marbles, with different geological history and thus different mineralogical and textural characteristics. Nevertheless the proposed 
method can provide a simple and fast alternative test for determination of the colour properties of limestones at a large (quarry) scale. Most important, the method can be extended to other fillers such as talc and/or kaolin and can involve other colouring mineral impurities, such as Ti-oxides in the case of kaolin fillers or serpentine and/or chlorite in the case of talc.

The observed deviation between the theoretical and the experimental values of colour parameters is attributed to a series of factors. First the grain size of calcite is different in the various types of limestones and marbles. In the proposed model we used an industrial product with average grain size $3 \mu \mathrm{m}$, while the grain size of the limestones used to test the model had in general a considerably greater average grain size (10-15 $\mu \mathrm{m}$ according to Repouskou 2001). In general, ground marbles yielded a greater average grain size than ground limestones (Repouskou 2001). Grain size affects colour significantly, because it controls the size of the diffuse reflectance unit (Cervelle \& Moëlo 1990). The nature of impurities is also a possible important factor contributing to the deviation between the theoretical and the experimental values. In this study the main iron rich impurity is hematite. However goethite, amorphous Fe-oxyhydroxides and/or to a lesser degree lepidocrocite are also possible Fe-oxyhydroxides present in limestones and their colour properties are different than hematite, thus affecting limestone colour to a different degree.

Organic carbon is an important impurity controlling colour. In most limestones organic matter is present in the form of kerogene, which is expected to impart different colour characteristics than the organic constituents of lignite, thus contributing further to the observed deviation between experimental and theoretical values. Also, both colouring impurities are multiphase materials consisting of several minerals, which affect colour. For instance the iron ore contains other colouring impurities such as Fe-rich chlorite and anatase, while the inorganic part of lignite contains a variety of minerals including calcite, quartz, mica, pyrite etc. Minerals like chlorite, anatase and pyrite affect colour and contribute to the observed deviation. Furthermore impurities in limestones may have different size than the size of hematite or lignitic constituents used to fomulate the model. Finally in limestones iron may be present in other forms except for oxides orland oxyhydroxides, such as Fecarbonates with different colour characteristics.

It is difficult to provide a model, which can take into account all those aforementioned parameters contributing to the deviation between experimental and theoretical values of colour properties of the limestones used to test the proposed model. However it should be noted, that although the uncertainty about the variables contributing to the deviation between experimental and theoretical is significant, the observed deviation is considered satisfactory and in the case of lightness $\left(\mathrm{L}^{*}\right)$ it is negligible. This is due to the fact that filler-grade white carbonates are pure materials with low abundance of colouring impurities. The greater deviation observed for $\Delta \mathrm{E}^{\star} \mathrm{ab}$ is attributed to the greater number of factors used to calculate to this parameter $\left(\mathrm{L}^{*}, \mathrm{a}^{*}\right.$ and $\left.\mathrm{b}^{*}\right)$ and thus increase the level of uncertainty in determination.

\section{CONCLUSIONS}

This study showed that the proposed model, which utilizes the $\mathrm{Fe}_{2} \mathrm{O}_{3}$ and organic carbon contents of calcite-rich carbonate rocks, could be used for determination of important colour parameters of such rocks, such as lightness $\left(L^{*}\right)$ and deviation from perfect white diffuser $\left(\Delta E^{*} a b\right)$. Moreover it can contribute to understand the dependence of colour properties on certain common phases present in carbonates. This is because the colour parameters vary systematically with increasing concentration of colouring impurities. The deviation between theoretical and experimental values for the two properties is satisfactory and is attributed to the limited number of carbonates used to calibrate the method. Similar results are also expected for brightness ( $Y$ ) if it is considered that the calculation of $L^{*}$ is based on determination of lightness. Most important, application of the proposed model will facilitate quality control in production units at quarry scale. The model can be extended to dolomites and dolomitic marbles, which decompose after firing at $800^{\circ} \mathrm{C}$. Among the parameters examined in this study, organic matter is the most important factor affecting the colour properties of carbonate rocks. 


\section{REFERENCES}

Adams J.M. 1993. Particle size and shape effects in materials science: examples from polymer and paper systems. Clay Minerals, 28, 509-530.

Bergman H. 1964. Geological Map of Greece. Kefalonia Sheet, scale 1:50,000.

Billmeyer F.W. \& Saltzman M. 1981 Principles of color technology, $2^{\text {nd }}$ edition. Pp 1-23, Wiley Interscience, New York.

British Standards Institution BS3900 1986. Parts D8, D9 and D10. Determination of colour and colour difference: principles, measurement and calculation.

Carr D.D., Rooney L.F. \& Freas R.C. 1994. Limestone and dolomite. In: Industrial Minerals and Rocks. (Carr D.D. editor). AIMME, pp. 605-609.

Cervelle B. \& Moëlo Y. 1990 Reflected light optics. In: Short Course on Advanced Microscopic Studies of Ore Minerals (Jambor J.L. \& Vaughan D.J. eds). Mineral. Ass. Canada Ottawa pp 87-108.

Christidis G., Makri P. \& Perdikatsis V. 2004. Influence of grinding on the colour properties of talc, bentonite and calcite white fillers. Clay Minerals (in press).

Christidis G., \& Scott, P.W. 1997. Origin and colour properties of white bentonites: A case study from the Aegean Islands of Milos and Kimolos, Greece. Miner. Deposita 32, 271-279.

Kotis Th., Ploumidis M., Metaxas A. \& Varvarousis G. 1992. Coal exploration of Vevi subarea, Florina District (W. Macedonia). Technical Report, IGME, $97 \mathrm{p}$ (in Greek).

Naydowski C., Hess P., Strauch D., Kuhlmann R. \& Rohleder, J. 2001. Calcium carbonate and its industrial applications. In: Calcium Carbonate. From the Cretaceous Period into the $21^{\text {st }}$ Century (Tegethoff F.W. editor), Birkhäuser Verlag, Basel, pp 197-311.

Repouskou E. 2001. Assessment of carbonate rocks from Crete Island in filler industry. Ph.D Thesis. Technical University of Crete. $218 p$ (in Greek).

Triantafyllou, G., Christidis, G. \& Markopoulos T. 2003. Influence of porosity and grain size of carbonate rocks on the reactivity of lime. In: Mineral Exploration and Sustainable development (Eliopoulos D. et al., eds) Millpress, Rotterdam, pp 931-934 